\title{
Occurrence and molecular characterization of cryptococcosis in dogs and cats in Mato Grosso, Brazil ${ }^{1}$
}

\begin{abstract}
Daphine A.J. de Paula², Arleana B.P. F. de Almeida ${ }^{3}$, Felipe S. da Cruz ${ }^{4}$, Fernando H. Furlan ${ }^{5}$, Edson M. Colodel ${ }^{3}$, Valéria R.F. Sousa ${ }^{3}$, Luciano Nakazato ${ }^{3}$ and Valéria Dutra ${ }^{3 *}$

ABSTRACT.- Paula D.A.J., Almeida A.B.P.F., Cruz F.S., Furlan F.H., Colodel E.M., Sousa V.R.F., Nakazato L. \& Dutra V. 2014. Occurrence and molecular characterization of cryptococcosis in dogs and cats in Mato Grosso, Brazil. Pesquisa Veterinária Brasileira 34(2):167172. Departamento de Clínica Médica Veterinária, Faculdade de Agronomia, Medicina Veterinária e Zootecnia, Universidade Federal de Mato Grosso, Av. Fernando Corrêa da Costa s/n, Bairro Boa Esperança, Cuiabá, MT 78068-900, Brazil. E-mail: valdutra@ufmt.br

Cryptococcosis is an infection that affects humans and animals, the etiology is attributed to Cryptococcus neoformans variety neoformans, C. neoformans var. grubii and Cryptococcus gattii. The infection is common in dogs and cats, causing respiratory, neurological, cutaneous and ocular infections. Aiming to better understand the epidemiology of cryptococcosis in animals in the region, this paper describe the occurrence and characterization of the Cryptococcus species involved in this illness in pet animals at Mato Grosso State, Brazil. Clinical samples of four cases, two in cats and two dogs, were submitted for pathological, microbiological and molecular analysis. Microscopically, in three cases, tissue sections stained with hematoxylin and eosin had absence to severe granulomatous reaction composed by histiocytes, multinucleated cells and lymphocytes infiltration. In one case, citological imprint analysis showed similar inflammatory mainly mononuclear and lymphocyte cells infiltration. All cases had variable amounts of intracellular and extracellular fungal structures compatible with Cryptococcus sp. on Periodic Acid-Schiff (PAS) stain. All clinical samples were positive for culture on Sabouraud Dextrose Agar (SDA) and morphologically classified as Cryptococcus sp. The isolates were PCR positive for $C$. gatti, being confirmed by sequencing technique. The findings characterize the molecular species involved in animal infections in the region, and may contribute to future studies of the epidemiology of C. gattii.
\end{abstract}

INDEX TERMS: Cryptococcus spp., cryptococcosis. mycosis, PCR, yeast, dogs, cats.

RESUMO.- [Ocorrência e caracterização da criptococose em cães e gatos em Mato Grosso.] A criptococose é uma infecção que afeta humanos e animais sendo a etiologia atribuída às espécies Cryptococcus neoformans variedade neoformans, C. neoformans var. grubii e C. gattii. A doença é

\footnotetext{
${ }^{1}$ Received on August 9, 2013.

Accepted for publication on December 6, 2013.

${ }^{2}$ Doutoranda do Programa de Pós-Graduação em Ciência da Saúde, Universidade Federal do Mato Grosso (UFMT), Av. Fernando Corrêa da Costa 2673, Coxipó, Cuiabá, MT 78060-900, Brazil.

${ }^{3}$ Departamento de Cínica Médica Veterinária, UFMT, Coxipó, Cuiabá, MT, Brazil. *Corresponding author: valdutra@ufmt.br

${ }^{4}$ Hospital Veterinário, UFMT, Coxipó, Cuiabá, MT, Brazil.

${ }^{5}$ Laboratório de Patologia Animal, Instituto de Ciências da Saúde, Centro Universitário de Sinop, UFMT, Av. Alexandre Ferronato 1200, Distrito Industrial, Sinop, MT 78550-000, Brazil.
}

comum em cães e gatos, causando infecções respiratórias, neurológicas, cutâneas e oculares. Com o objetivo de entender melhor a epidemiologia da criptococose em animais, este trabalho descreve a ocorrência e a caracterização de espécies de Cryptococcus em pequenos animais doentes no Estado de Mato Grosso, Brasil. Amostras clínicas de quatro casos, dois em felinos e dois em caninos, foram submetidas à análise patológica, microbiológica e molecular. Microscopicamente, em três casos, nos cortes de tecidos corados pela hematoxilina notou-se desde ausência até acentuada inflamação granulomatosa composta por histiócitos, células multinucleadas e infiltração linfocitária. Em um caso, na análise citológica de "imprint" observou-se infiltrado inflamatório similar composto principalmente por células mononucleares e linfócitos. Em todos os casos havia variável quantidade de estruturas fúngicas intra e extracelulares 
compatíveis com Cryptococcus spp pela coloração do ácido períodico de Schiff (PAS). Todas as amostras foram positivas para a cultura em Sabouraud Dextrose Agar (SDA), e morfologicamente classificadas como Cryptococcus sp. Os isolados foram positivos no PCR para C. gattii, sendo confirmados pelo seqüenciamento. Os resultados caracterizaram a espécie envolvida na região, e contribuem para futuros estudos sobre a epidemiologia de C. gattii.

TERMOS DE INDEXAÇÃO: Cryptococcus spp., criptococcose, micoses, PCR, levedura, caninos, felinos.

\section{INTRODUCTION}

Cryptococcosis is a systemic disease, which occurs due to inhalation of fungal propagules in the environment (Casadevall \& Perfect 1998). After establishment of lung disease, the basidiomycetous yeast can spread via hematogenous, reaching the central nervous system causing meningitis or meningoencephalitis (Chayakulkeeree \& Perfect 2006, Ma \& May 2009). Cryptococcus gattii is one of the etiologic agents of cryptococcosis in humans and animals. This yeast belongs to the species complex Cryptococcus neoformans, comprising the species $C$. neoformans var. neoformans, C. neoformans var. grubii and C. gattii (Lin \& Heitman 2006).

C. gattii is typically found in tropical and subtropical climate areas and the ecological niche was initially attributed to Eucalyptus spp. However cavities in decaying trunks and branches of various species of trees are also the habitat of this fungus (Ellis \& Pfeiffer 1990, Sorrell et al. 1996). C. gattii acquired an ability to colonize new bio-climatic regions, which caused an outbreak of infection in humans and animals in Vancouver - Canada (Sorrell 2001). The change in the epidemiology of this fungus is probably a consequence of ecology and biology alterations of the yeast thus demonstrating its potential to cause disease in humans and animals (Dixit et al. 2009). The increased in the number of affected animals in outbreaks of cryptococcosis, not only in dogs and cats, but also other species suggests an increased susceptibility to infection of the animals and their role as sentinel species (Stephen et al. 2002, Duncan et al. 2006, Byrnes et al. 2009). Aiming to better understand the epidemiology of cryptococcosis in animals in the region, this paper describe the occurrence and characterization of the Cryptococcus species involved in this illness in pet animals at Mato Grosso State, Brazil.

\section{MATERIALS AND METHODS}

Samples of four animals with suspected cryptococcosis were sent to the Laboratory of Veterinary Pathology and Veterinary Microbiology, Federal University of Mato Grosso, during August 2011 to March 2012. Clinical and epidemiological data, and the material collected for laboratory of animals are depicted in Table 1.

Cytological smears from one cat was stained by Panotico Fast ${ }^{\circledR}$ technique and periodic acid-Schiff (PAS). Biopsies of a cat and one dog and tissues collected during necropsy of a dog and one cat were fixed in buffered formalin solution (10\%), stained with hematoxylin-eosin (HE), Periodic acid-Schiff (PAS) (Prophet et al. 1992) and method-methanamine silver (GMS) (Grocott 1955).

For fungal isolation, fragments of the samples were washed in sterile saline plus antibiotics (ampicillin 50mg/L), macerated, plated on Sabouraud Dextrose Agar and Niger (Guizotia abyssinica) Agar. The culture was incubated at $37^{\circ} \mathrm{C}$ and observed daily. Morphological analysis of microscopic suspected colonies was performed with lactophenol cotton blue and India ink dyes.

Molecular characterization was performed by PCR and sequencing. For DNA extraction of isolates, we used the method with glass beads, described by Del Poeta et al. (1999). To determine the species of the isolates were used primer pairs CNA 70S and CNA 70AS to C. neoformans, and, CNB 49S and CNB 49AS to C. gattii (Aoki et al. 1999, Horta et al. 2002, Casali et al. 2003). PCR positive samples were subjected to partial sequencing of $\mathrm{Cu}-\mathrm{Zn}$ superoxide dismutase gene (SOD1), (D’Souza et al. 2004) in ABI 3500 (Applied Biosystem). The sequences obtained were analyzed using the BLASTN of the Broad Institute (www.broadinstitute.mit.edu).

\section{RESULTS AND DISCUSSION}

The animals in this study showed distinct forms of the disease, as shown in Table 1. At necropsy, Case 1, a canine had multiple nodules consistently slightly firm, whitish on the cut surface of variable size coalescing in the abdominal cavity, forming irregular mass which occupied almost all of the omentum liver, spleen and peritoneum (Fig.1). Case 2, a canine with a firm irregular skin nodule in head with no additional clinical signal. Case 3 was an adult cat with coughing, sneezing and respiratory distress, which lung had a consolidation in cranial areas (Fig.2). Case 4 was a cat with an ulcerated reddish nodule in nose. Only this animal was treated unsuccessfully with itraconazole $(10 \mathrm{mg} / \mathrm{kg})$ during 40 days but died after this period.

Microscopically, all cases had presence of spherical

Table 1. Canine and feline cryptococcosis characteristics: epidemiological, clinical and pathological findings

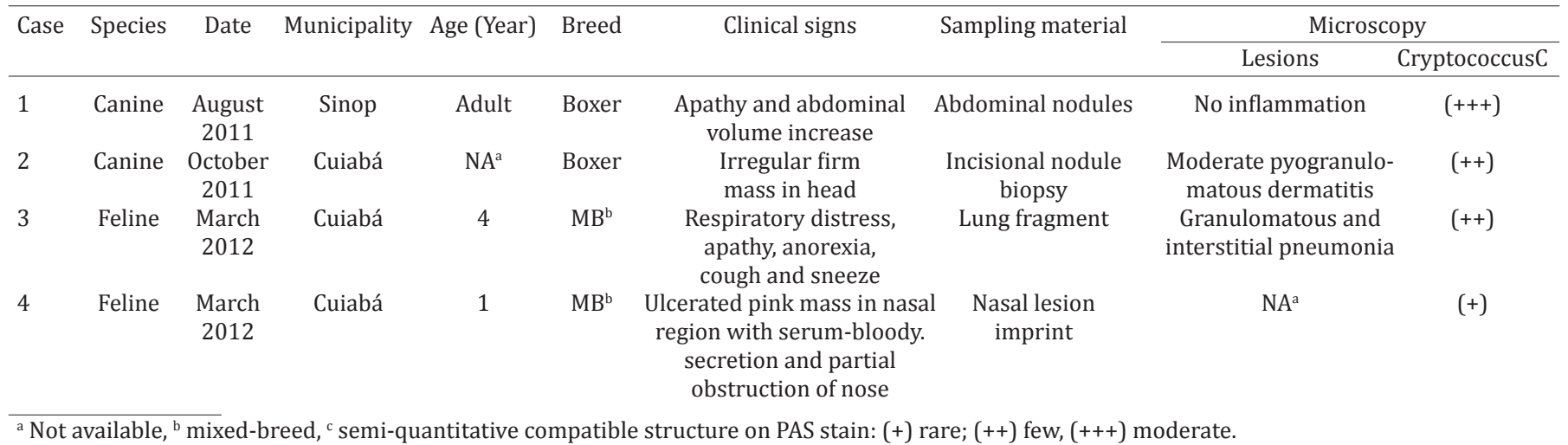




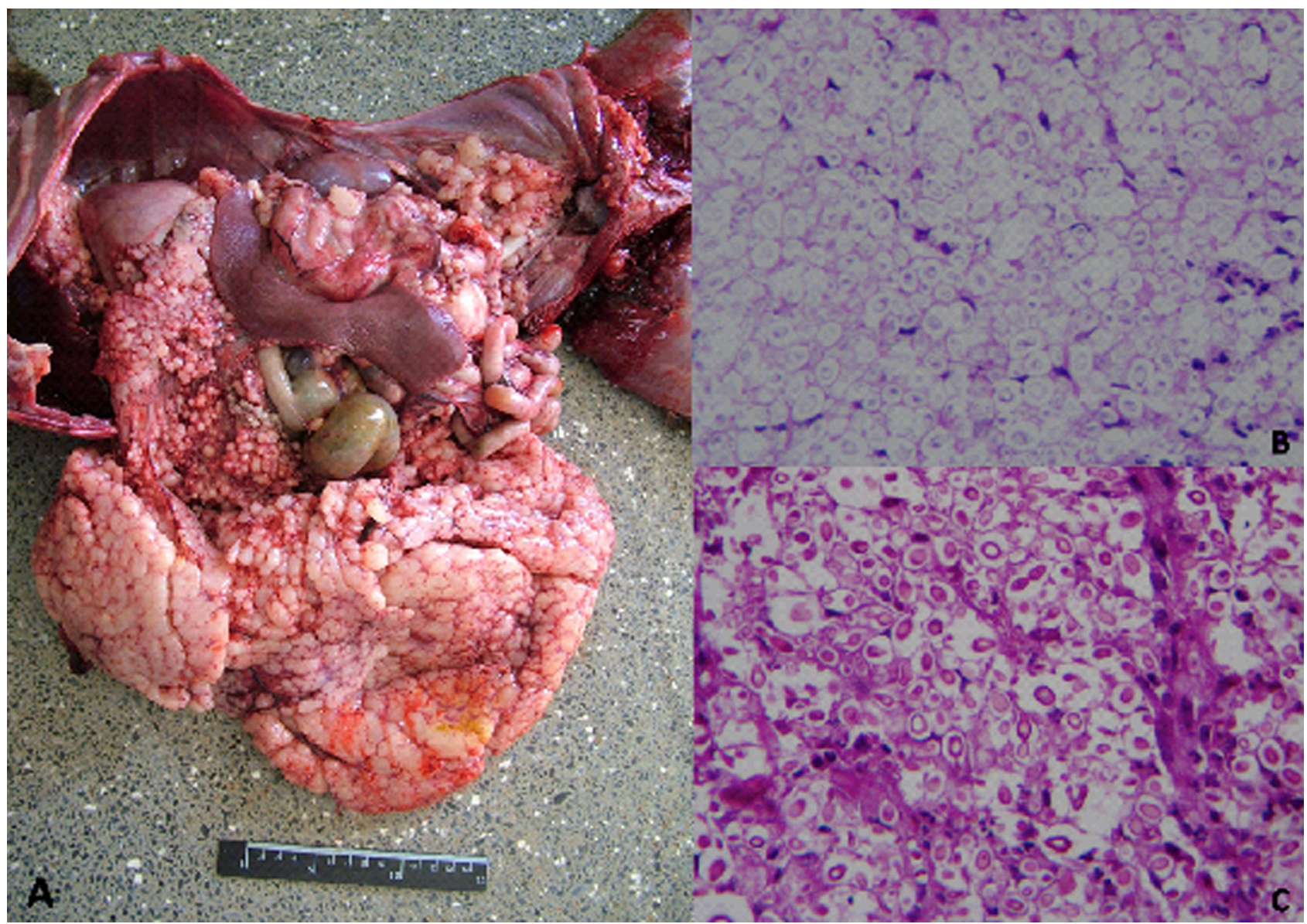

Fig.1. Case 1, dog, abdominal cavity with Cryptococcus gattii. (A) There is marked proliferation of tissue whitish multinodular in almost all abdominal serous surfaces. (B) Abdominal adipose tissue with absence of inflammatory reaction and numerous structures morphologically consistent with Cryptococcus. HE stain, 20x. (C) Rounded, oval or elongated yeast-like structures by PAS, 20x.

structures morphologically compatible with Cryptococcus sp. witch was surrounded by a polysaccharide capsule confluent that were PAS and GMS positive (Fig.1C and 2C). There were no inflammatory cells in Case 1 . Case 2 and 3 exhibited mainly granulomatous inflamation composed of polymorphonuclear cell infiltrates, few histiocytes, multinucleated cells and lymphocytes. On cytological analysis, Case 4 had the same patterns of cell infiltration seen in Case 2 and 3.

In all cases there was isolation of colonies with surface appearance shiny, smooth, creamy consistency with the mucoid and white to beige after $48 \mathrm{~h}$ in SDA. In Niger agar, the colonies had brown, but with varying intensity. Microscopically these colonies were formed by cells round or oval, surrounded by a capsule of varying thickness surrounded by a clear halo. Based on histological and morphological colony isolates were classified in the genus Cryptococcus sp. Colony isolates from all cases were PCR positive to C. gattii. Sequencing analysis showed $98 \%$ similarity to the corresponding SOD1 gene of $C$. gattii R265 (Broad Institute CNBG_0599) in cases 2, 3 and 4, identified by GenBank accession number, as follows: KF412801, KF412798, KF412799 respectively, and Case 1 (KF412800) shared $99 \%$ of similarity.
Diagnostic confirmation in reported cases was based on clinical data, histopathology, and culture through molecular detection. Cryptococcosis occurs in most species of mammals, especially dogs and cats, with similar clinical presentations of the disease both in C. neoformans and $C$. gattii, however C. gattii is more virulent (Lester et al. 2011). The manifestations of the infection are usually severe and often may lead to the death both in humans and animals (Byrnes et al. 2011), as in Case 1, 3 and 4 of this study. In cats, cryptococcosis can occur in animals of any age, has no predilection for race or sex. The infection is associated with exposure of animals to external environments (Malik et al. 1992, Lester et al. 2004, O’Brien et al. 2004). In these animals is common the formation of polyps or masses firmer subcutaneous tissue, mainly on the cartilage in the nose, leading to the appearance of "clown nose", as reported in the Case 4. Fungal granulomas may also occur in lymph nodes and skin around the head and neck and occasionally the central nervous system (CNS) is reached (Kerl 2003). Infections may involve lungs and pleura, however, infections of the lower respiratory tract, as observed in the Case 3 , are less common in cats. In Brazil, cryptococcosis in cats was reported causing infections in the respiratory tract and skin in Rio Grande do Sul, Pernambuco and Mato Grosso 


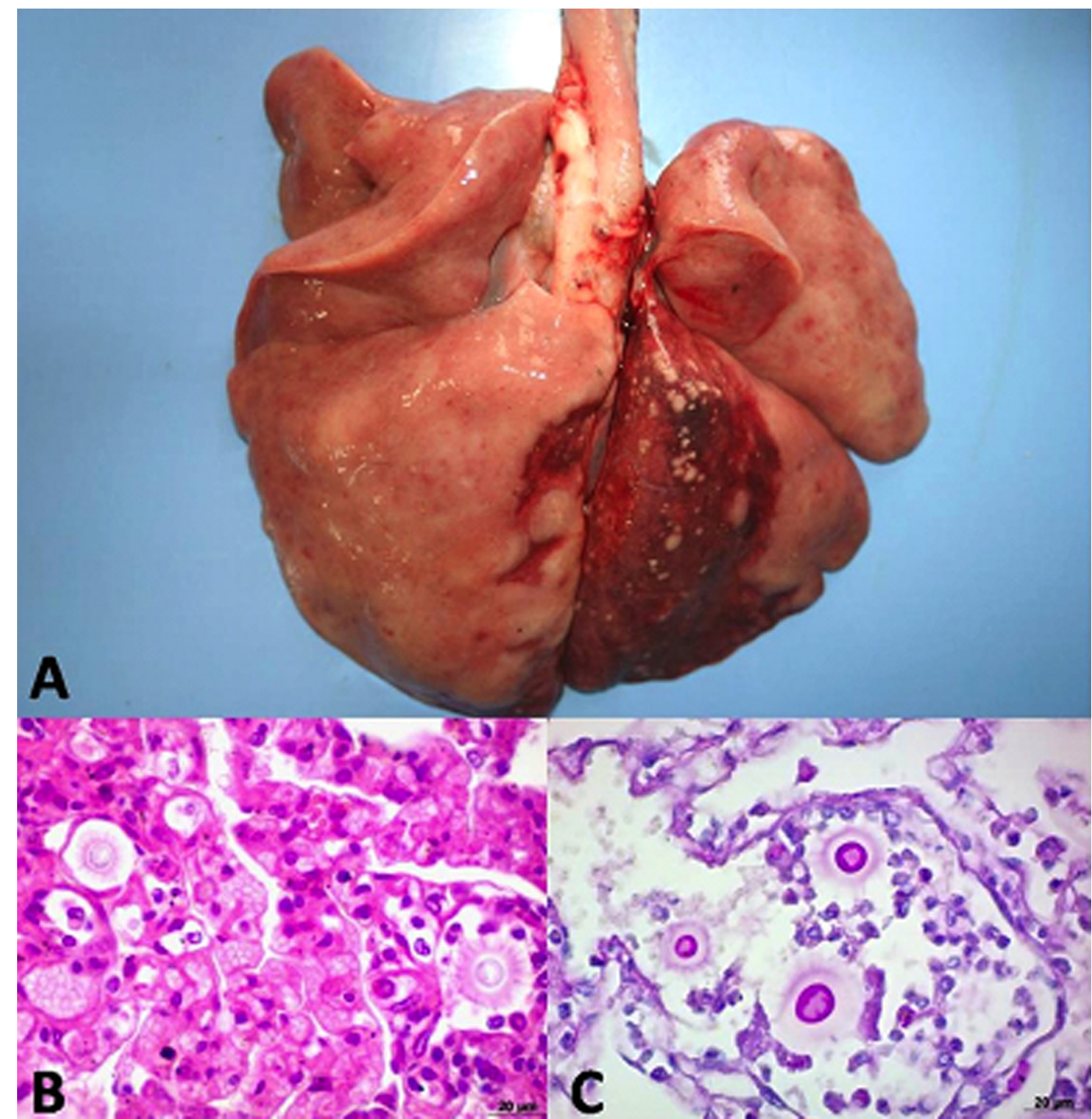

Fig.2. Case 3, cat lung with Cryptococcus gattii. (A) Irregular extensive focal consolidation area affecting diaphragmatic lobes. (B) Alveolar septa thickened with mixed infiltrated inflammatory cells and numerous thin walled rounded structures surrounded by clear halos similar to Cryptococcus. HE stain, 20x. (C) This yeast-like structures are evident by PAS stain, 20x.

do Sul State (Sant'ana et al. 1999, Pinto Filho et al. 2003, Juliano et al. 2006). Canine cryptococcosis in Brazil are described in São Paulo, Rio Grande do Sul and Paraná (Honsho et al. 2003, Marcasso et al. 2005, Martins et al. 2008, Rondelli et al. 2010) causing neurological, dermatological and disseminated. In all animal cases in Brazil, one case was confirmed with $C$. neoformas var. neoformans serotype D (Martins et al. 2008), majority methodology to confirm and classified Cryptococcus was based mainly on positive silver stain on tissue and isolation on SDA.

In this study causes of immunosuppression were only investigated in Case 4 through Snap FIV- FeLV Coombo test IDEXX commercial kit. However, the animal had no positivity to retroviral infections like feline leukemia virus ( $F e L V)$ and feline immunodeficiency virus (FIV). According to Lester et al. (2011), cryptococcosis caused by C. gattii, it is a primary mycosis, this is not common in cats with retroviral infections, however, these infections may have a negative impact on response to therapy (Malik et al. 1992, Walker et al. 1995, Lester et al. 2004, Tisdall et al. 2007).

The dogs often show clinical signs of neurological and/ or ophthalmic, although the respiratory tract may also be involved (Malik et al. 1992, Lester et al. 2004, McGill et al. 2009). Skin lesions mainly in the skin of the head and neck, as observed in the Case 2 are more frequently in cats than in dogs. The intra abdominal form observed in Case 1 occurs rarely and may affect other organs such as liver, spleen and gastrointestinal tract (Malik et al. 1992, Lester et al. 2004). In Case 2, 3 and 4 infection probably occurred due to inhalation of spores environmental, due to the presence of the fungus spores in soil, decaying plant material, excreta of birds, which are found in both urban and rural areas in Brazil (Pappalardo \& Melhem 2003). In animals, the spread of infection to other organs may be a result of the number of propagules inhaled environmental microorganism, virulence and host immunity isolated. It 
is believed that the spread of the respiratory tract to other body sites such as skin, bone, the brain is related to intracellular optional feature of the yeast, using phagocytic cells of the host to spread more efficiently and escape the immune response (Schop 2007, Giles et al. 2009, Ma \& May 2009). The ingestion of a large number of micro-organism may result in gastrointestinal lesions, as observed in Case 4. However, this is considered atypical form of clinical manifestation (Lester et al. 2004). The microbiological and histopathological findings in this study are characteristic of yeast, confirmed by molecular techniques such as PCR and sequencing. Although molecular techniques are not used in routine clinical practice, these results demonstrate good sensitivity and specificity when compared with the gold standard methods. In this work, the use of this diagnostic approach helped in the characterization of yeast species-level which may contribute to epidemiological studies of the disease in the region. According to the sequence data, the four isolates, both of animals belonging to city Cuiabá and Sinop, showed identity with VGII genotype.

The C. gattii molecular type VGII accounted for approximately $95 \%$ of infections in the outbreak of cryptococcosis in Canada and the United States and was also isolated in Brazil in human cases and environment samples (Kidd et al. 2004, Kidd et al. 2007, MacDougall et al. 2007, Trilles et al. 2008, Byrnes et al. 2010). Epidemiological studies of isolates belonging to sub-type genotypes molecular VGII (MacDougall et al. 2007), has drawn attention to these emerging strains of $C$. gattii in animal and humans since they possess a high degree of adaptability and mainly because mostly infect immunocompetent individuals. Animal cases happen about six months before human cases in endemic areas, thus this could be an important tool of surveillance (MacDougall et al. 2007).

To date there are few data regarding the occurrence of C. gattii in animals in the region, which limits the understanding of the population genetic structure and ecology of cryptococcosis. Such data are of great importance to describe and monitor the occurrence and expansion of genotypes Cryptococcus spp. highly virulent in animals. This study supports a surveillance to human and animal infection population in Mato Grosso, Brazil.

Acknowledgements.- The study was supported by grants from Coordenação de Aperfeiçoamento de Pessoal de Nível Superior (CAPES), Conselho Nacional de Desenvolvimento Científico e Tecnológico (CNPq) and FAPEMAT.

\section{REFERENCES}

Aoki F.H., Imai T., Tanaka R., Mikami Y., Taguchi H., Nishimura N.F., Nishimura K., Miyaji M., Schreiber A.Z. \& Branchini M.L. 1999. New PCR primer pairs specific for Cryptococcus neoformans serotype A or B prepared on the basis of random amplified polymorphic DNA fingerprint pattern analyses. J. Clin. Microbiol. 37:315-320.

Byrnes E.J., Bildfell R.J., Dearing P.L., Valentine B.A. \& Heitman J. 2009. Cryptococcus gattii with bimorphic colony types in a dog in western Oregon: additional evidence for expansion of the Vancouver Island outbreak. J. Vet. Diagn. Invest. 21:133-136.

Byrnes E.J., Li W., Lewit Y., Ma H., Voelz K., Ren P., Carter D.A., Chaturvedi V., Bildfell R.J., May R.C. \& Heitman J. 2010. Emergence and pathogenicity of highly virulent Cryptococcus gattii genotypes in the northwest United States. PLoS Pathog. 6, and 1000850.

Byrnes E.J., Bartlett K.H., Perfect J.R. \& Heitman J. 2011. Cryptococcus gattii: an emerging fungal pathogen infecting humans and animals. Microbes Infect. 13:895-907.

Casadevall A. \& Perfect J.R. 1998. Cryptococcus neoformans. American Society for Microbiology Press, Washington, DC. 541p.

Casali A.K., Goulart L., Rosa e Silva L.K., Ribeiro A.M., Amaral A.A., Alves S.H., Schrank A., Meyer W. \& Vainstein M.H. 2003. Molecular typing of clinical and environmental Cryptococcus neoformans isolates in the Brazilian state Rio Grande do Sul. FEMS Yeast Res. 3:405-415.

Chayakulkeeree M. \& Perfect J.R. 2006. Cryptococcosis. Infect Dis. Clin. North Am. 20:507-544, v-vi.

D’Souza C.A., Hagen F., Boekhout T., Cox G.M. \& Heitman J. 2004. Investigation of the basis of virulence in serotype A strains of Cryptococcus neoformans from apparently immunocompetent individuals. Curr. Genet. 46:92-102.

Del Poeta M., Toffaletti D.L., Rude T.H., Dykstra C.C., Heitman J. \& Perfect J.R. 1999. Topoisomerase I is essential in Cryptococcus neoformans: role in pathobiology and as an antifungal target. Genetics. 152:167-178.

Dixit A., Carroll S.F. \& Qureshi S.T. 2009. Cryptococcus gattii: an emerging cause of fungal disease in North America. Interdiscip. Perspect. Infect. Dis., p.1-13.

Duncan C., Schwantje H., Stephen C., Campbell J. \& Bartlett K. 2006. Cryptococcus gattii in wildlife of Vancouver Island, British Columbia, Canada. J. Wildl. Dis. 42:175-178.

Ellis D.H. \& Pfeiffer T.J. 1990. Natural habitat of Cryptococcus neoformans var. gattii. J. Clin. Microbiol. 28:1642-1644.

Giles S.S., Dagenais T.R., Botts M.R., Keller N.P. \& Hull C.M. 2009. Elucidating the pathogenesis of spores from the human fungal pathogen Cryptococcus neoformans. Infect. Immun. 77:3491-3500.

Grocott R.G. 1955. A stain for fungi in tissue sections and smears using Gomori's methenamine-silver nitrate technic. Am. J. Clin. Pathol. 25: 975-979.

Honsho C.S., Mine S.Y., Oriá A.P., Benato N., Camacho A.A., Alessi A.C. \& Laus J.L. 2003. Generalized systemic cryptococcosis in a dog after immunosuppressive corticotherapy. Arq. Bras. Med. Vet. Zootec. 55:155-159.

Horta J.A., Staats C.C., Casali A.K., Ribeiro A.M., Schrank I.S., Schrank A. \& Vainstein M.H. 2002. Epidemiological aspects of clinical and environmental Cryptococcus neoformans isolates in the Brazilian state Rio Grande do Sul. Med. Mycol. 40:565-571.

Juliano R.S., Souza A.I. \& Sheide R. 2006. Criptococose Felina. Revta Patol. Trop. 35:65-70.

Kerl M.E. 2003. Update on canine and feline fungal diseases. Vet. Clin. North Am. Small Anim. Pract. 33:721-747.

Kidd S.E., Hagen F., Tscharke R.L., Huynh M., Bartlett K.H., Fyfe M., Macdougall L., Boekhout T., Kwon-Chung K.J. \& Meyer W. 2004. A rare genotype of Cryptococcus gattii caused the cryptococcosis outbreak on Vancouver Island (British Columbia, Canada). Proc. Natl Acad. Sci. USA 101:17258-17263.

Kidd S.E., Bach P.J., Hingston A.O., Mak S., Chow Y., MacDougall L., Kronstad J.W. \& Bartlett K.H. 2007. Cryptococcus gattii dispersal mechanisms, British Columbia, Canada. Emerg. Infect. Dis. 13:51-57.

Lester S.J., Kowalewich N.J., Bartlett K.H., Krockenberger M.B., Fairfax T.M. \& Malik R. 2004. Clinicopathologic features of an unusual outbreak of cryptococcosis in dogs, cats, ferrets, and a bird: 38 cases (January to July 2003). J. Am. Vet. Med. Assoc. 225:1716-1722.

Lester S.J., Malik R., Bartlett K.H. \& Duncan C.G. 2011. Cryptococcosis: update and emergence of Cryptococcus gattii. Vet. Clin. Pathol. 40:4-17.

Lin X. \& Heitman J. 2006. The biology of the Cryptococcus neoformans species complex. Annu. Rev. Microbiol. 60:69-105.

Ma H. \& May R. 2009. Virulence in Cryptococcus species. Adv. Appl. Microbiol. 67:131-190.

MacDougall L., Kidd S.E., Galanis E., Mak S., Leslie M.J., Cieslak P.R., Kronstad J.W., Morshed M.G. \& Bartlett K.H. 2007. Spread of Cryptococcus gat- 
tii in British Columbia, Canada, and detection in the Pacific Northwest, USA. Emerg. Infect. Dis. 13:42-50.

Malik R., Wigney D.I., Muir D.B., Gregory D.J. \& Love D.N. 1992. Cryptococcosis in cats: clinical and mycological assessment of 29 cases and evaluation of treatment using orally administered fluconazole. J. Med. Vet. Mycol. 30:133-144.

Marcasso R.A., Sierra S., Arias M.V.B., Bracarense A.P.F.R.L., Yamamura A.A.M., Biasi F., Lopes B.A., Amude A.M. \& Cortêz D.E.A. 2005. Cryptococcosis in nervous system of dogs-report of three cases. Semina, Ciênc. Agrárias 26:229-238.

Martins D.B., Barbosa A.L.T., Cavalheiro A., Lopes S.T.A., Santurio J.M., Schossler J.E. \& Mazzanti A. 2008. Diagnosis of canine cryptococcosis by fine-needle aspiration cytology. Ciência Rural 38:826-829.

McGill S., Malik R., Saul N., Beetson S., Secombe C., Robertson I. \& Irwin P. 2009. Cryptococcosis in domestic animals in Western Australia: a retrospective study from 1995-2006. Med. Mycol. 47:625-639.

O’Brien C.R., Krockenberger M.B., Wigney D.I., Martin P. \& Malik R. 2004. Retrospective study of feline and canine cryptococcosis in Australia from 1981 to 2001: 195 cases. Med. Mycol. 42:449-460.

Pappalardo M.C. \& Melhem M.S. 2003. Cryptococcosis: a review of the Brazilian experience for the disease. Revta Inst. Med. Trop. São Paulo 45:299-305.

Pinto Filho S.T.L., Pereira D.I.B., Sallis E.S.V., Henriques G.B. \& Dalmolin F. 2003. Criptococose nasal e cutânea em felino: relato de caso. MEDVEP, Revta Cient. Med. Vet. 2:33-37.

Prophet E.B., Mills B., Arrington J.B. \& Sobin L.H. 1992. Laboratory Methods in Histotechnology. American Registry of Pathology, Washinton, DC. 278 p.
Rondelli M.C.H., Nogueira A.F.S., Anai L.A., Gava F.N., Borin S., Ondani A.C., Campos Filho E., Tinucci-Costa E. \& Santana A.E. 2010. Cryptococcosis diagnosed by imprints of oral mucosa lesions in dog. Arq. Bras. Med. Vet. Zootec. 62:1271-1274.

Sant'Ana F.J.F., Maia F.C.L., Gomes Filho J.B., Silveira A.B. \& Silva V.R. 1999. Cryptococosis in cats. Arq. Bras. Med. Vet. Zootec. 51:333-334.

Schop J. 2007. Protective immunity against Cryptococcus neoformans infection. McGill J. Med. 10:35-43.

Sorrell T.C. 2001. Cryptococcus neoformans variety gattii. Med. Mycol. 39:155-168.

Sorrell T.C., Chen S.C., Ruma P., Meyer W., Pfeiffer T.J., Ellis D.H. \& Brownlee A.G. 1996. Concordance of clinical and environmental isolates of Cryptococcus neoformans var. gattii by random amplification of polymorphic DNA analysis and PCR fingerprinting. J. Clin. Microbiol. 34:1253-1260.

Stephen C., Lester S., Black W., Fyfe M. \& Raverty S. 2002. Multispecies outbreak of cryptococcosis on southern Vancouver Island, British Columbia. Can. Vet. J. 43:792-794.

Tisdall P.L., Martin P. \& Malik R. 2007. Cryptic disease in a cat with painful and swollen hocks: an exercise in diagnostic reasoning and clinical decision-making. J. Feline Med. Surg. 9:418-423.

Trilles L., Lazéra M.O.S., Wanke B., Oliveira R.V., Barbosa G.G., Nishikawa M.M., Morales B.P. \& Meyer W. 2008. Regional pattern of the molecular types of Cryptococcus neoformans and Cryptococcus gattii in Brazil. Mem. Inst. Oswaldo Cruz 103:455-462.

Walker C., Malik R. \& Canfield P.J. 1995. Analysis of leucocytes and lymphocyte subsets in cats with naturally-occurring cryptococcosis but differing feline immunodeficiency virus status. Aust. Vet. J. 72:93-97. 